\title{
EVALUATION OF A MODEL TO SIMULATE NET RADIATION OVER A VINEYARD CV. CABERNET SAUVIGNON
}

\author{
Marcos Carrasco ${ }^{1}$, and Samuel Ortega-Farías ${ }^{1 *}$
}

\begin{abstract}
A B S T R A C T
Net radiation $(\mathrm{Rn})$ is the main energy balance component controlling evaporation and transpiration processes. In this regard, this study evaluated two models to estimate Rno above a commercial vineyard (Vitis vinifera cv. Cabernet Sauvignon) located in Pencahue Valley, Maule Region ( $35^{\circ} 22^{\prime} \mathrm{S}$; $71^{\circ} 47^{\prime} \mathrm{W}$; 75 m.a.s.1.). An automatic meteorological station (AMS) was installed in the central part of the vineyard and used to measure $\mathrm{Rn}$, solar radiation (Rsi), air temperature $(\mathrm{Ta})$, canopy temperature $(\mathrm{Tf})$ and relative humidity (RH). On a $30 \mathrm{~min}$ interval, results indicated that model Rne1 (assuming Ta $\neq \mathrm{Tf}$ ) and model Rne2 (assuming $\mathrm{Ta}=\mathrm{Tf}$ ) were able to estimate $\mathrm{Rn}$ with a mean absolute error (MAE) of less than $40 \mathrm{~W} \mathrm{~m}^{-2}$ and root mean square error (RMSE) of less than $61 \mathrm{~W} \mathrm{~m}^{-2}$. On daily intervals, the two models estimated Rno with MAE and RMSE values of less than 1.68 and 1.75 MJ m ${ }^{-2} \mathrm{~d}^{-1}$, respectively. In global terms, the models presented errors below 9 and $11 \%$ on 30 min and daily intervals, respectively. Furthermore, this study indicated that the incorporation of canopy temperature did not improve the Rno estimation substantially, in spite of having a temperature gradient $(\mathrm{dT}=\mathrm{Tf}-\mathrm{Ta})$ between -3 and $4{ }^{\circ} \mathrm{C}$. These results suggest that an Rne 2 model could be used to estimate Rno using Rsi, Ta and RH measurements.
\end{abstract}

Key words: atmospheric emissivity, terrestrial radiation, atmospheric radiation, energy balance, Vitis vinifera.

\section{INTRODUCTION}

Recent reports have indicated that it is possible to estimate directly actual evapotranspiration (ET) of vineyards using complex models that determine water consumption by compartments, where soil evaporation and plant transpiration are quantified separately. A model with these characteristics is the Shuttleworth and Wallace (S-W) model, which has been able to adequately compute the actual ET of several row crops (Daamen and McNaughton, 2000; Anadranistakis et al., 2000; Kato et al., 2004). Studies carried out in vineyards by Sene (1994) and Ortega-Farías et al. (2007) have suggested that the S-W model can be used for direct estimation of ET, using weather information generated by an AMS installed within the vineyard. In this case, the S-W model requires an adequate parameterization of the energy balance of the vineyard, where net radiation $(\mathrm{Rn})$ is the main component that provides the energy needed for soil evaporation, transpiration and heat transference among the canopy, soil surface and air. Unfortunately, most of the AMS found in the market do not measure Rn directly, therefore, it must be calculated by physical models which use solar radiation (Rsi), air temperature (Ta), canopy temperature $(\mathrm{Tf})$ and relative humidity $(\mathrm{RH})$ as inputs (Iziomon et al., 2000; Irmak et al., 2003; Ortega-Farías et al., 2004).

Net radiation, representing the balance between short $(0.15$ to $3 \mu \mathrm{m})$ and long wave radiation (3 to $100 \mu \mathrm{m})$, is defined as (Arya, 2001):

$$
\mathrm{Rn}=\mathrm{Rsi}-\mathrm{Rsr}+\mathrm{Rli}-\mathrm{Rlr}=(1-\alpha) \mathrm{R} s \mathrm{i}+\mathrm{Rli}-\mathrm{R} l \mathrm{r}
$$

\footnotetext{
${ }^{1}$ Universidad de Talca, Facultad de Ciencias Agrarias, Centro de Investigación y Transferencia en Riego y Agroclimatología (CITRA), Casilla 747, Talca, Chile.

E-mail: sortega@utalca.cl *Corresponding author.

Received: 2 February $2007 . \quad$ Accepted: 6 June 2007.
} 
where $\mathrm{Rn}=$ net radiation $\left(\mathrm{W} \mathrm{m}^{-2}\right)$; $\mathrm{Rsi}=$ solar radiation $\left(\mathrm{W} \mathrm{m}^{-2}\right) ; \mathrm{Rsr}=$ reflected solar radiation $\left(\mathrm{W} \mathrm{m}^{-2}\right) ; \mathrm{Rli}=$ atmospheric (or incoming longwave) radiation $\left(\mathrm{W} \mathrm{m}^{-2}\right)$; $\mathrm{Rlr}=$ terrestrial (or outgoing longwave) radiation (W $\mathrm{m}^{-2}$ ), and $\alpha=$ albedo (adimensional).

The ratio of Rsr to Rsi (or albedo) is usually used for computing $\mathrm{Rn}$ and depends on canopy characteristics. Therefore, albedo is determined by the training system, vineyard geometry, plant density and vegetation coverage (Pieri and Gaudillère, 2003). On the other hand, Rli and Rlr are calculated according to the Stefan-Boltzman Law and depend on air and canopy temperature, respectively (Monteith and Unsworth, 1990). Considering the above, Equation [1] can be expressed as (Campbell, 1995):

$\mathrm{Rn}=(1-\alpha) \mathrm{Rsi}+\varepsilon_{\mathrm{a}} \sigma \mathrm{T}_{\mathrm{a}}^{4}-\varepsilon_{\mathrm{f}} \sigma \mathrm{T}_{\mathrm{f}}^{4}$

where $\varepsilon_{\mathrm{a}}=$ emissivity of the air (adimensional), $\sigma=$ Stefan-Boltzman constant $\left(5.6710^{-8} \mathrm{~W} \mathrm{~m}^{-2} \mathrm{~K}^{-4}\right)$, $\mathrm{Ta}=$ air temperature $\left({ }^{\circ} \mathrm{K}\right), \mathrm{T}_{\mathrm{f}}=$ canopy temperature $\left({ }^{\circ} \mathrm{K}\right), \varepsilon_{\mathrm{f}}=$ emissivity of the canopy. The value of $\varepsilon_{\mathrm{f}}$ is relatively constant and an average value of 0.98 is employed in many agricultural applications (Allen et al., 1998). The value of $\varepsilon_{\mathrm{a}}$, which depends on the type of cloud, cloud cover degree, atmospheric humidity and air temperature, can be calculated as (OrtegaFarías et al., 2004):

$\varepsilon_{\mathrm{a}}=\phi\left(\frac{\mathrm{e}_{\mathrm{w}}}{\mathrm{T}_{\mathrm{a}}}\right)^{\frac{1}{7}}$

where $\phi=$ empiric coefficient; $\mathrm{e}_{\mathrm{w}}=$ vapor pressure $(\mathrm{kPa})$.

Since there are no studies in Chile in relation to modeling of vineyard energy balance, the objective of this research was to evaluate two models to simulate net radiation over a commercial Cabernet Sauvignon vineyard, trained on a vertical shoot-positioned (VSP) system, under clear and cloudy sky conditions.

\section{MATERIALS AND METHODS}

In order to evaluate two models for computing the net radiation over a vineyard (Vitis vinifera $\mathrm{L}$. cv. Cabernet Sauvignon), data were collected during the 2003-2004 and 2004-2005 growing seasons. For this purpose, an agroclimatic unit was installed within a 10-year-old vineyard, planted on a North-South orientation, and located in the Pencahue Valley, Maule Region, Chile ( $35^{\circ} 22^{\prime} \mathrm{S} ; 7^{\circ} 47^{\prime} \mathrm{W}$; 75 m.a.s.l.).
The climate of the Pencahue Valley is temperate semiarid, averaging maximum and minimum summer temperatures of 31 and $11{ }^{\circ} \mathrm{C}$, respectively. Mean annual precipitation is $700 \mathrm{~mm}$, with a dry period of 7 months (Research and Transference Center of Irrigation and Agroclimatology (CITRA) base data, Universidad de Talca). The soil at the vineyard is classified as Cunculén series (Aquic Palexeralfs) with a sandy loam texture (CIREN-CORFO, 1997). The effective roots depth is concentrated on the top $60 \mathrm{~cm}$ of soil, due to the presence of a compacted layer that does not allow root growth and water infiltration at greater depths. For the first $60 \mathrm{~cm}$ depth, the bulk density (Da), field capacity (FC) and wilting point (PWP) were $1.44 \mathrm{~g} \mathrm{~cm}^{-3}, 180.0 \mathrm{~mm}$ and $66.0 \mathrm{~mm}$, respectively.

The agroclimatic unit had an area of 4 ha, with a plant density of 2778 plants ha-1 $^{-1}(3.0 \mathrm{~m}$ between rows and $1.2 \mathrm{~m}$ between vines). The vines were trained on a vertical shoot-positioned (VSP) system (1.5 m high) and pruned with 24 shoots per vines. During both seasons the vineyard was managed in optimum agronomic conditions concerning fertilization, phytosanitary control and irrigation. A drip irrigation system was used with a dripper discharge of $3.5 \mathrm{~L} \mathrm{~h}^{-1}$ and irrigation management was conducted using the volumetric soil water content measured at the effective rooting depth (0-60 cm) (Acevedo et al., 2005). These measurements were carried out twice a week with a TDR reflectometer (Time Domain Reflectometry, Trase System 6050X1, Santa Bárbara, California, USA) during both growing seasons. For this study, leaf area index (LAI) ranged between 0.99 and 1.39 and between 0.81 and 0.88 for the 2003-2004 and 2004-2005 seasons, respectively. In this case, LAI was estimated according to the methodology used by Ortega-Farías et al. (2007).

An AMS (Campbell Scientific, Logan, Utah, USA) was installed in the center of the agroclimatic unit to simultaneously measure air temperature $(\mathrm{Ta})$, canopy or foliage temperature (Tf), air humidity (RH), solar radiation (Rsi) and net radiation ( $\mathrm{Rn}$ ) on 30-min time intervals. The model of sensors, units and height of installation above ground level are shown in Table 1.

To implement the Rn model, values of $\varepsilon_{\mathrm{f}}$ and $\alpha$ equivalent to 0.98 and 0.18 , respectively, were used for this study. In this case, albedo value was measured by a four-way net radiometer (CNR1. Kipp \& Zonen Inc., Delft, The Netherlands), which measures short 
Table 1. Climatic variables, model of sensors and height of installation above ground level

\begin{tabular}{llc}
\hline Variable & \multicolumn{1}{c}{$\begin{array}{c}\text { Sensor } \\
\text { model }\end{array}$} & $\begin{array}{c}\text { Height above } \\
\text { ground level } \\
(\mathbf{m})\end{array}$ \\
\hline Air temperature, ${ }^{\circ} \mathrm{C}$ & Vaisala (HMP35C) & 2.7 \\
Relative humidity, $\%$ & Vaisala (HMP35C) & 2.7 \\
Canopy temperature, ${ }^{\circ} \mathrm{C}$ & Vaisala (HMP35C) & 1.2 \\
Solar radiation, $\mathrm{W} \mathrm{m}^{-2}$ & LI200X & 3.5 \\
Net radiation, $\mathrm{W} \mathrm{m}^{-2}$ & REBS Q7.1. & 3.5 \\
\hline
\end{tabular}

and long wave radiation of Equation [1]. The CNR1 was installed above a drip-irrigated Merlot vineyard trained on a vertical shoot-positioned system, whose canopy characteristics (canopy shape, vineyard geometry, and vegetation coverage) were similar to those observed in this study. In a similar manner, Pieri and Gaudillère (2003) found an albedo of 0.20 for a trellis system, where the ratio of the canopy height to row spacing was equivalent to 0.91 . As well, using non-linear optimization analysis on the same database, it was found that the empiric coefficient $(\phi)$ (Equation [3]) was equivalent to 1.51 and 1.91 for daytime (Rsi $>0)$ and night $(\mathrm{Rsi}<0)$ hours, respectively.

To evaluate the behavior of the model (Equation [2]), the estimated net radiation (Rne) was compared with the net radiation (Rno) measured from a net radiometer installed on the AMS. The validation of the model was done assuming a temperature gradient (dT) between foliage and air different from zero (Rne1 model) and equal to zero (Rne2 model). In this case, Rne1 and Rne 2 models required two and one temperature measurement levels, respectively. The automatic meteorological stations used in agricultural production currently have one measurement level.

As statistical parameters the comparison included the mean absolute error (MAE), root mean square error (RMSE) and ratio (b) of the observed (Rno) to estimated (Rne1, Rne2) values of net radiation (Ortega-Farías et al., 2006). The Z-test was included to evaluate if $b$ value was statistically different from unity (one) at $95 \%$ confidence levels.

\section{RESULTS AND DISCUSSION}

The vapor pressure deficit (VPD) increased gradually during the morning, reaching maximum values between 17:00 and 18:00 h, when the highest atmospheric demand for water vapor took place (Figure 1). The maximum mean values of VPD were 3.1 and $3.4 \mathrm{kPa}$ for 2003-2004 and 2004-2005 seasons, respectively. The greater variability of VPD was found during 2004-2005 season, where the standard deviation (SD) for the maximum atmospheric demand for water vapor was $1.2 \mathrm{kPa}$. On the other hand, the a) $2003-2004$

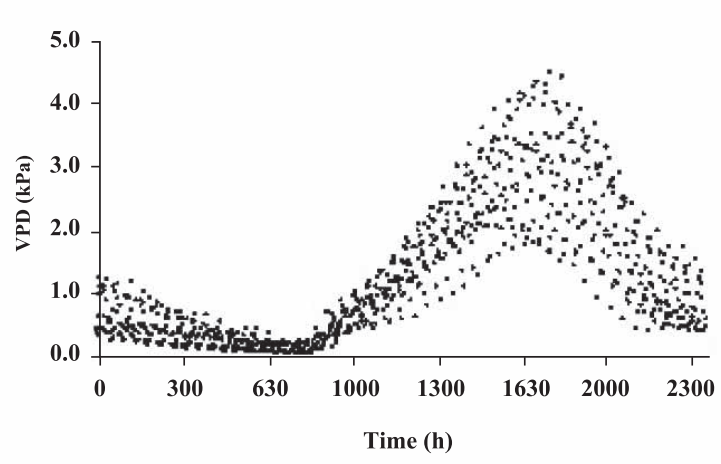

b) $2004-2005$

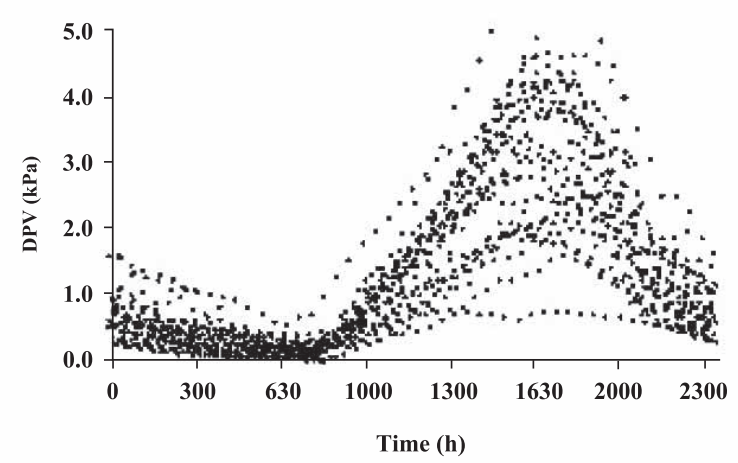

Figure 1. Daytime variation of vapor pressure deficit (VPD) in a cv. Cabernet Sauvignon commercial vineyard during (a) 2003-2004 and (b) 2004-2005 growing seasons. Pencahue Valley, Chile. 
dT values were positive and negative during the daytime and nighttime, respectively (Figure 2). The dT values increased slowly from the beginning of the day to reach a maximum in the afternoon, and diminished as solar radiation levels decreased. The minimum and maximum dT values were -3 and $4{ }^{\circ} \mathrm{C}$ $\left(\mathrm{SD} \pm 1.8^{\circ} \mathrm{C}\right)$ for both seasons. The Rne2 model, which assumes $\mathrm{Ta}=\mathrm{Tf}$, Ortega-Farías et al. (2004) indicated that it is very important to keep the crop under optimum soil water conditions, in order to minimize dT and reduce potential errors in the estimation of terrestrial radiation.

Similar to VPD, the maximum dT values were found between 17:00 and 18:00 h, with a maximum variability observed during the second season. Concerning the behavior of the dT, Ortega-Farías et al. (2000) indicated that in the case of crops and pastures, foliage and air temperatures do not usually have the same pattern during the daytime. In this case, the foliage temperature reached its maximum value at solar noon, while air temperature reached its maximum at the end of the afternoon; therefore, the maximum value of dT was observed at midday. For the vineyard, maximum values of dT were observed $2 \mathrm{~h}$ after maximum solar irradiation $(15: 00 \mathrm{~h})$, coinciding with the maximum values of VPD.

During both seasons there was a good global comparison between Rno vs. Rne1 and Rno vs. Rne2 for clear and cloudy days (Tables 2 and 3). For both season, the average values of $b$ were higher than 0.92 , with values of MAE and RMSE less than 34 and 48 $\mathrm{W} \mathrm{m}{ }^{-2}$, respectively. The worst performance of the Rne1 and Rne2 models was found on cloudy days, where $b$ values varied between 0.91 and 0.93 . For clear and cloudy days, the results of the Z-test indicated that the $b$ value was significantly different from unity (one), suggesting that proposed models (Rne1 and Rne2) tended to overestimate the Rno values, with errors varying between 7 and 9\%. Besides, Figures 3 and 4 show that the points presented a regular distribution along the 1:1 line, with a trend of Rne1 and Rne 2 models to underestimate the observed net radiation below $200 \mathrm{~W} \mathrm{~m}^{-2}$. Furthermore Figures $3 \mathrm{~b}$ and $4 \mathrm{~b}$ show that the 2004-2005 season had a higher point dispersion along the 1:1 line, as compared to the 2003-2004 season. On the other hand, the statistical analysis indicated that the use of the canopy temperature in the calculation of terrestrial radiation did not improve Rno estimations, since MAE, RMSE and $b$ values for Rne 1 and Rne 2 models were similar for both seasons and atmospheric conditions (Tables 2 and 3 ).

In both seasons, the worst adjustments of the models were found for cloudy atmospheric conditions, with maximum MAE and RMSE values equivalent to 40 and $61 \mathrm{~W} \mathrm{~m}^{-2}$, respectively (Tables 2 and 3). Similar results have been reported by Ortega-Farías et al. (2004) in a tomato (Lycopersicon esculentum Mill.) crop, where the Rn model showed the largest errors on cloudy days, which did not exceed $250 \mathrm{~W} \mathrm{~m}^{-2}$ and did not significantly affect the daily estimation of Rn. As well, Ortega-Farías et al. (2000) indicated that errors in the calculation of Rn over a well-irrigated festuca (Festuca arundinacea) grass were associated with the estimation of atmospheric radiation under cloudy sky conditions. According to Brotzge and Deuchon (2000) and Brotzge and Crawford (2003),
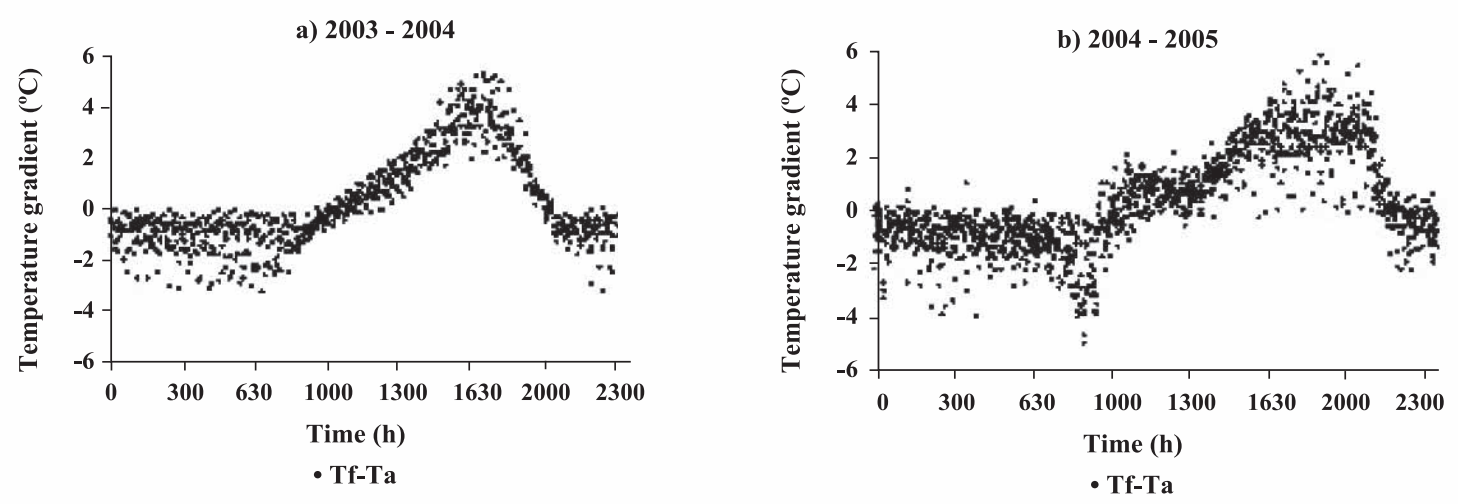

Figure 2. Daytime variation of temperature gradient between canopy (Tf) and air (Ta) in a cv. Cabernet Sauvignon commercial vineyard during (a) 2003-2004 and (b) 2004-2005 seasons. Pencahue Valley, Chile. 
Table 2. Statistical analysis for the net radiation model (Rne1) assuming a temperature gradient between the canopy and air different from zero $(\mathrm{Ta} \neq \mathrm{Tf})$.

\begin{tabular}{lcccc}
\hline & MAE & RMSE & b value & Z-Test \\
\cline { 2 - 3 } & & & & \\
\hline a) $2003-2004$ season & & 35 & 0.93 & $\mathrm{~F}$ \\
Clear day & 26 & 46 & 0.91 & $\mathrm{~F}$ \\
Cloudy day & 31 & 40 & 0.94 & $\mathrm{~F}$ \\
Average & 28 & & & \\
b) 2004-2005 season & 27 & 40 & 0.93 & $\mathrm{~F}$ \\
Clear day & 40 & 61 & 0.93 & $\mathrm{~F}$ \\
Cloudy day & 33 & 50 & 0.93 & $\mathrm{~F}$ \\
Average & 31 & 45 & 0.94 & $\mathrm{~F}$ \\
Average both seasons & &
\end{tabular}

MAE: mean absolute error; RMSE: root mean square error; b: ratio of the observed (Rno) to estimated (Rne1) values of net radiation; $\mathrm{V}$ : Null hypothesis $(\mathrm{b}=1) ; \mathrm{F}$ : alternative hypothesis $(\mathrm{b} \neq 1)$; Ta: air temperature $\left({ }^{\circ} \mathrm{C}\right)$; Tf: canopy temperature $\left({ }^{\circ} \mathrm{C}\right)$.

Table 3. Statistical analysis for the net radiation model (Rne2) assuming a temperature gradient between the canopy and air equal to zero $(\mathrm{Ta}=\mathrm{Tf})$.

\begin{tabular}{|c|c|c|c|c|c|}
\hline & & MAE & RMSE & \multirow[t]{2}{*}{ b value } & \multirow[t]{2}{*}{ Test-Z } \\
\hline & & & & & \\
\hline \multicolumn{6}{|c|}{ a) 2003-2004 season } \\
\hline & Clear day & 33 & 39 & 0.92 & $\mathrm{~F}$ \\
\hline & Cloudy day & 38 & 49 & 0.91 & $\mathrm{~F}$ \\
\hline & Average & 34 & 44 & 0.92 & $\mathrm{~F}$ \\
\hline \multicolumn{6}{|c|}{ b) $2004-2005$ season } \\
\hline & Clear day & 29 & 42 & 0.91 & $\mathrm{~F}$ \\
\hline & Cloudy day & 39 & 60 & 0.91 & $\mathrm{~F}$ \\
\hline & Average & 34 & 51 & 0.91 & $\mathrm{~F}$ \\
\hline & erage both seasons & 34 & 48 & 0.92 & \\
\hline
\end{tabular}

MAE: mean absolute error; RMSE: square of the mean error; b: ratio of the observed (Rno) to estimated (Rne2) values of net radiation; $\mathrm{V}=$ Null hypothesis $(\mathrm{b}=1) ; \mathrm{F}=$ alternative hypothesis $(\mathrm{b} \neq 1) ; \mathrm{Ta}=$ air temperature $\left({ }^{\circ} \mathrm{C}\right) ; \mathrm{Tf}=$ canopy temperature $\left({ }^{\circ} \mathrm{C}\right)$.

the probable causes of potential errors in the estimation of Rn on cloudy days were associated with the parameterization of air emissivity, which depends on vapor pressure and air temperature at the reference level.

For clear days, it was observed that the net radiation increased gradually during the morning and reached a maximum value around 14:00 $\mathrm{h}$, diminishing and taking negative values near 20:00 h (Figure 5). The figure indicates that daytime and nighttime variations of Rne1 and Rne2 were very similar to those of Rno with maximum differences between 13:00 and 14:00 $\mathrm{h}$. In this case, Equation [2] overestimated net radiation between 12:00 and 16:00 h, with best and worst comparisons observed on days 51 (Figure 5c) and 39 (Figure 5b), respectively. For both seasons, the maximum MAE $\left(38 \mathrm{~W} \mathrm{~m}^{-2}\right)$ and $\operatorname{RMSE}\left(39 \mathrm{~W} \mathrm{~m}^{-2}\right)$ values were observed on day 39 , when the daily value of Rno was about $52 \%$ of the daily solar radiation (31 $\left.M J \mathrm{~m}^{-2} \mathrm{~d}^{-1}\right)$.

For cloudy days, Figure 6 indicates that daytime variations of Rno, Rne1 and Rne2 were significantly affected by the distribution and intensity of cloudiness, so they did not show regular patterns during daytime, as in the case of clear days. A good comparison was observed between Rno vs. Rne1 and Rno vs. Rne2 with errors that did not exceed $9 \%(b=0.91)$ during the 2003-2004 and 2004-2005 seasons. The best and worst comparisons for this study were observed on days 46 (Figure 6a) and 43 (Figure 6d), respectively. On day 43, MAE and RMSE values were equal to 54 and $88 \mathrm{~W} \mathrm{~m}^{-2}$, respectively. On cloudy days, the largest errors were associated with rapid changes in solar radiation during short periods of time. Under these 

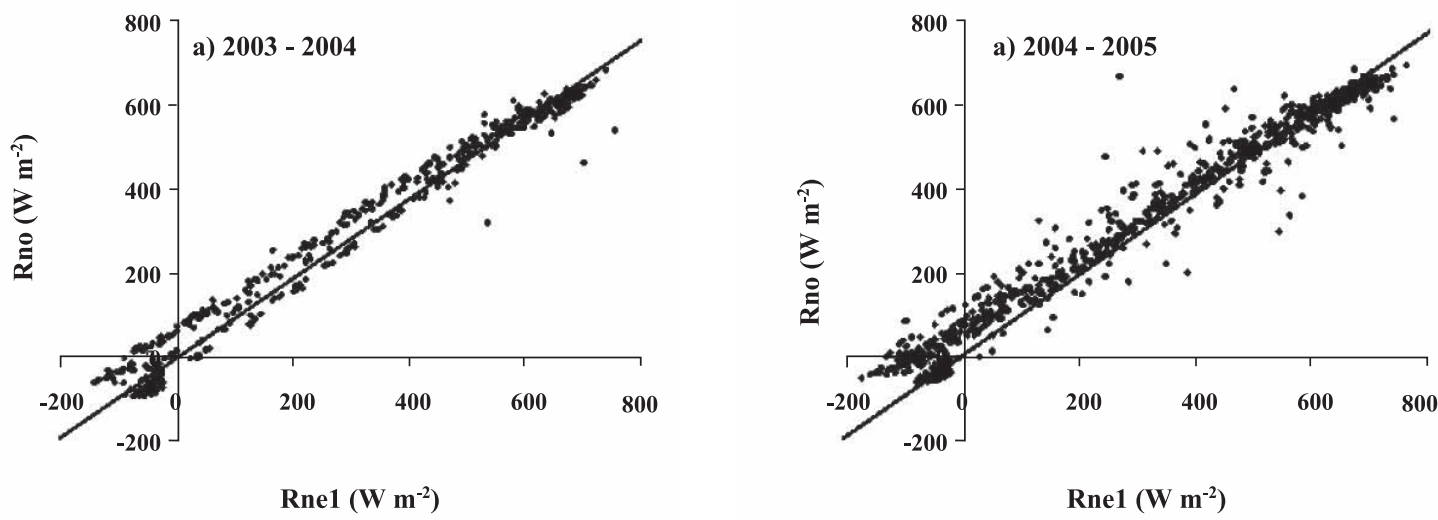

Figure 3. Comparison between observed (Rno) and estimated (Rne) net radiation in a commercial vineyard cv. Cabernet Sauvignon during the 2003-2004 and 2004-2005 seasons. In this case, Rn was calculated assuming a temperature gradient between the air and canopy different from zero.
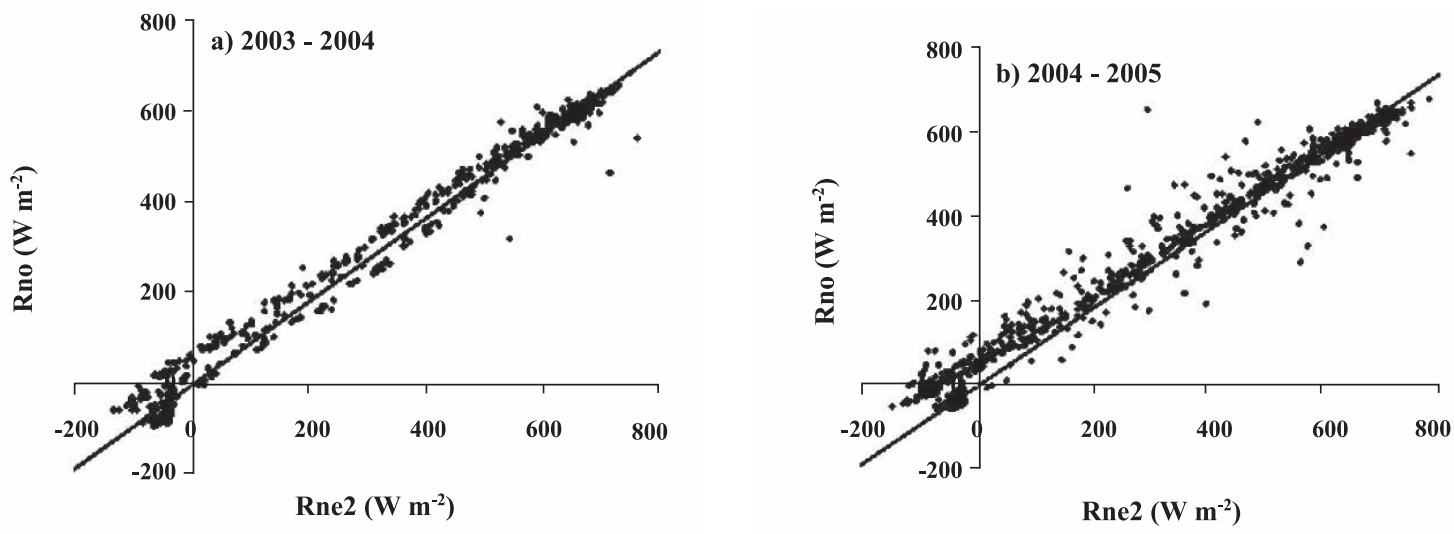

Figure 4. Comparison between observed (Rno) and estimated (Rne) net radiation in a commercial vineyard cv. Cabernet Sauvignon during the 2003-2004 and 2004-2005 seasons. In this case, Rn was calculated assuming a temperature gradient between the air and canopy equal to zero.

conditions, the estimation of air emissivity can induce errors in the calculation of atmospheric radiation and therefore in the final calculation of Rno.

Daily comparison between Rno vs. Rne1 and Rno vs. Rne2 showed a good agreement with maximum MAE and RMSE values equivalent to 1.68 and $1.75 \mathrm{MJ}$ $\mathrm{m}^{-2} \mathrm{~d}^{-1}$, respectively (Table 4 ). In both seasons, the Ztest indicated that the $b$ value was significantly different from unity (one), indicating that Rnel and Rne2 tended to overestimate daily Rno, with errors varying between 2 and $11 \%$. In general, net radiation was overestimated and underestimated by the two models for levels of Rno below $8 \mathrm{MJ} \mathrm{m}^{-2} \mathrm{~d}^{-1}$ and 14.8 $M J ~ m^{-2} \mathrm{~d}^{-1}$, respectively (Figure 7).
It is important to point out that the Rne2 model was able to estimate net radiation with a good degree of precision even though the temperature gradient between canopy and air (dT) ranged from -3 to $4{ }^{\circ} \mathrm{C}$ (Figure 2). Similar results were reported by OrtegaFarías et al. (2004) indicating that the Rne 2 model showed a $3.2 \%$ error in the estimation of net radiation over a tomato crop, in spite of having a dT that varied between -5 and $5{ }^{\circ} \mathrm{C}$. Therefore the practical application of the Rne 2 model requires maintaining the vineyard in optimum soil water conditions to minimize dT. It is also important to indicate that soil surface can produce a high level of sensible heat $(\mathrm{H})$, which could potentially increase the canopy temperature. The production of sensible heat depends 

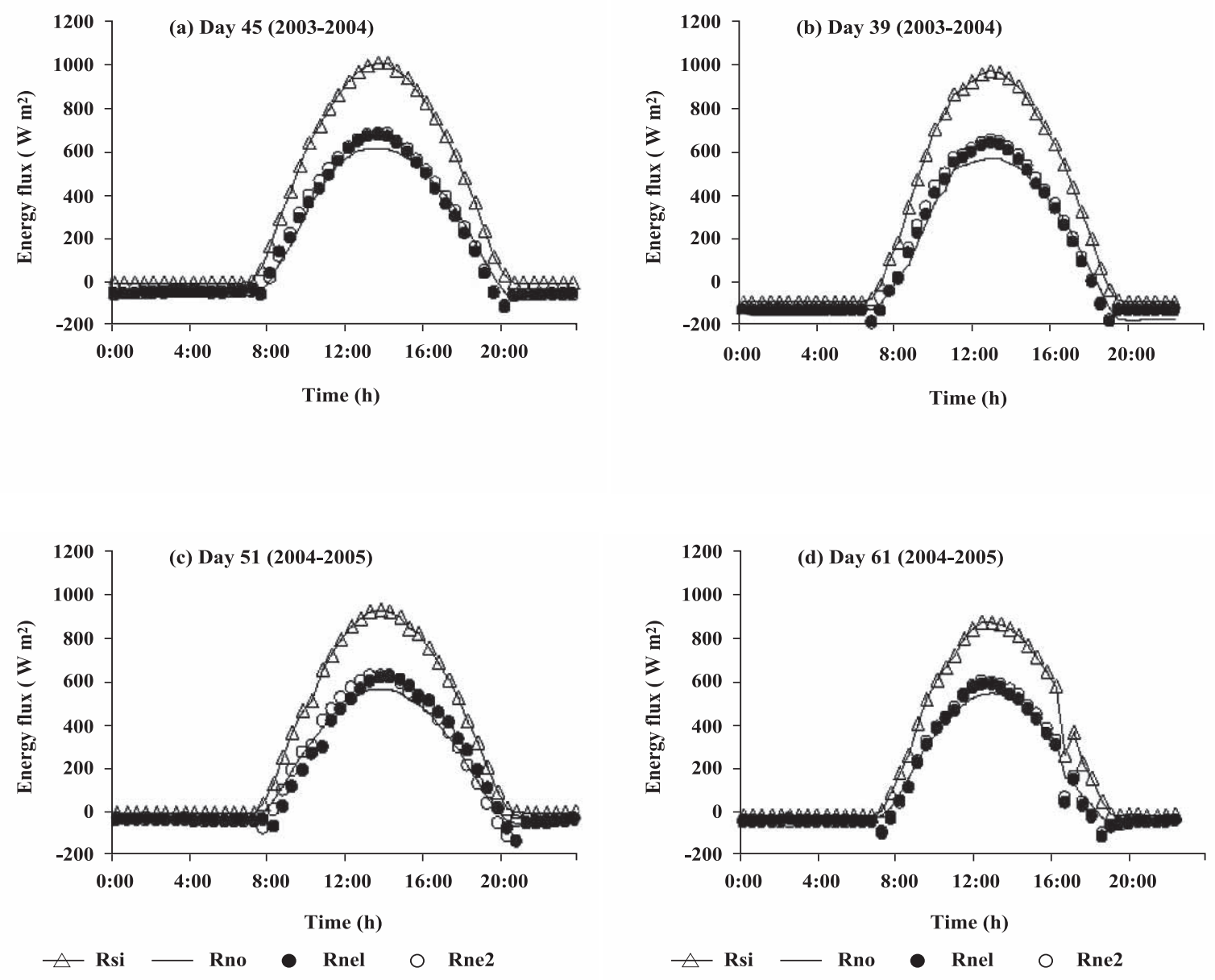

Figure 5. Daily variation of observed (Rno) and estimated (Rne) net radiation assuming a temperature gradient between canopy (Tf) and air (Ta) different (Rne1) from or equal (Rne2) to zero for clear days during the 20032004 and 2004-2005 seasons. Solar radiation (Rsi) was included as a reference.

Table 4. Statistical analysis for the calculation of daily net radiation values assuming a temperature gradient between the canopy and air different to $(\mathrm{Ta} \neq \mathrm{Tf})$ or equal to zero $(\mathrm{Ta}=\mathrm{Tf})$.

\begin{tabular}{|c|c|c|c|c|c|}
\hline & & MAE & RMSE & b value & Z-Test \\
\hline & & $-\mathbf{N}$ & & & \\
\hline a) & $\mathrm{Ta} \neq \mathrm{Tf}($ Rnel model $)$ & & & & \\
\hline & 2003-2004 season & 1.29 & 1.37 & 0.92 & $\mathrm{~F}$ \\
\hline & 2004-2005 season & 0.78 & 1.05 & 0.98 & $\mathrm{~F}$ \\
\hline & Average & 1.04 & 1.21 & 0.95 & $\mathrm{~F}$ \\
\hline b) & $\mathrm{Ta}=\mathrm{Tf}($ Rne2 model $)$ & & & & \\
\hline & 2003-2004 season & 1.68 & 1.75 & 0.89 & $\mathrm{~F}$ \\
\hline & 2004-2005 season & 0.93 & 1.16 & 0.96 & $\mathrm{~F}$ \\
\hline & erage & 1.31 & 1.50 & 0.93 & $\mathrm{~F}$ \\
\hline
\end{tabular}

MAE: mean absolute error; RMSE root mean square error; b: ratio of the observed (Rno) to estimated (Rne1 and Rne2) values of net radiation; $\mathrm{V}=$ Null hypothesis $(\mathrm{b}=1) ; \mathrm{F}=$ alternative hypothesis $(\mathrm{b} \neq 1) ; \mathrm{Ta}=$ air temperature $\left({ }^{\circ} \mathrm{C}\right) ; \mathrm{Tf}=$ canopy temperature $\left({ }^{\circ} \mathrm{C}\right)$. 

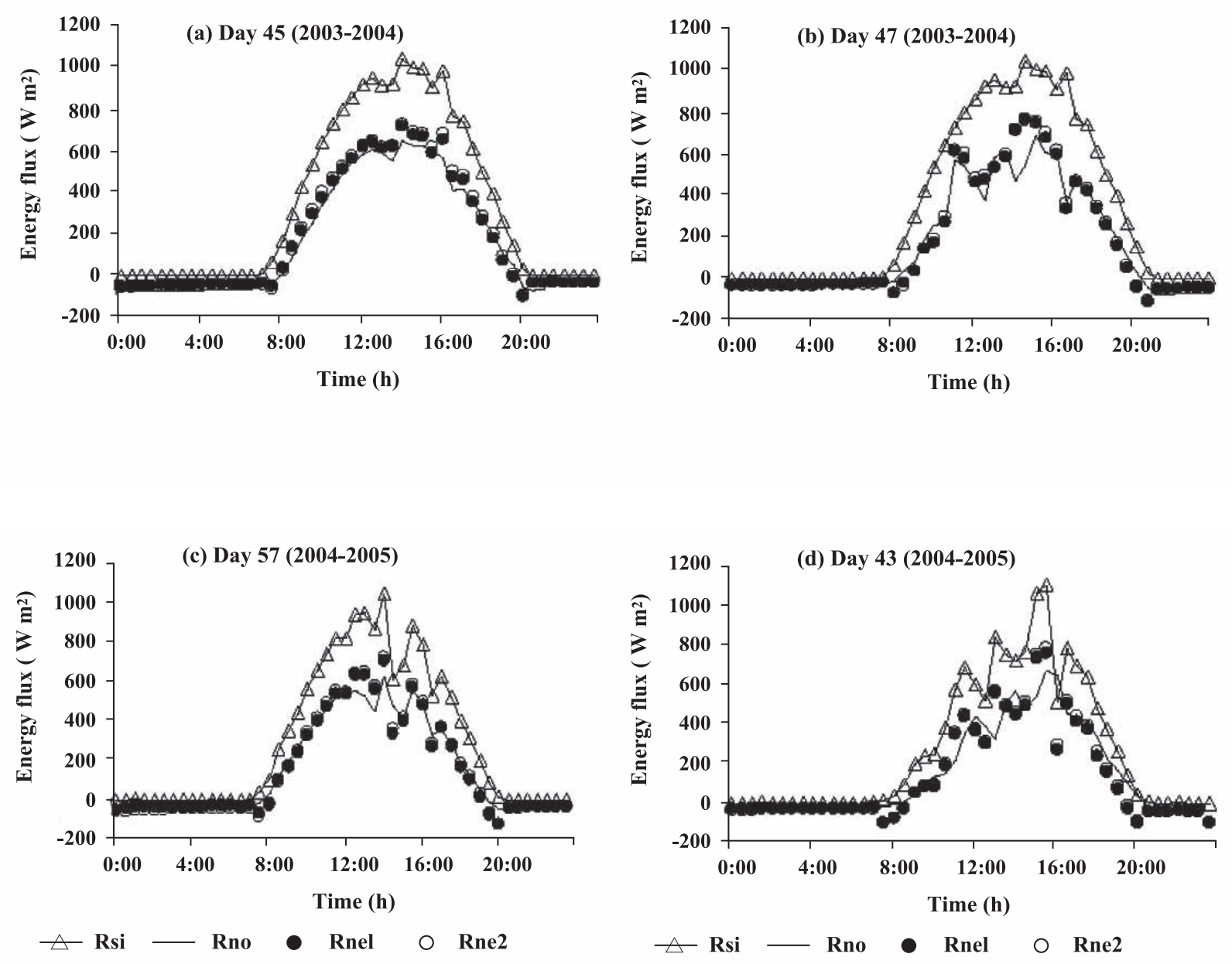

Figure 6. Daily variation of observed (Rno) and estimated (Rne) net radiation assuming a temperature gradient between canopy (Tf) and air (Ta), different (Rne1) from or equal (Rne2) to zero, for cloudy days during the 2003-2004 and 2004-2005 seasons. Solar radiation (Rsi) was included as a reference.
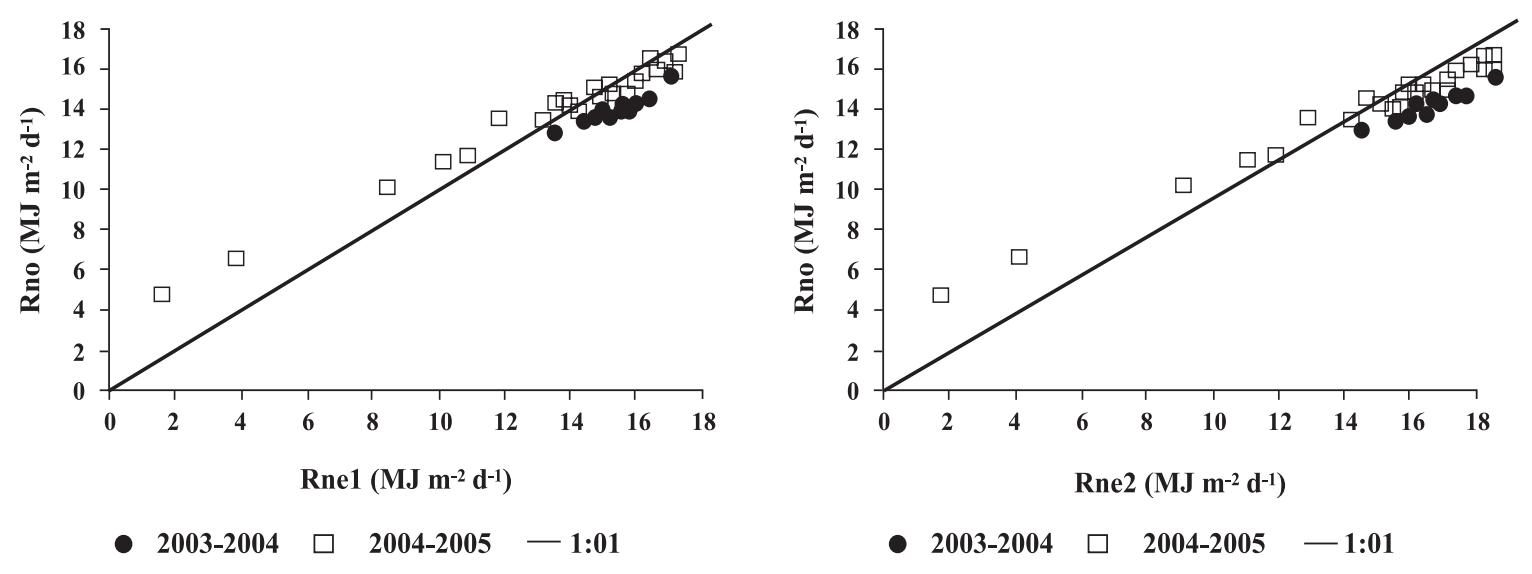

Figure 7. Daily comparison between observed (Rno) and estimated (Rne) net radiation assuming a temperature gradient between canopy and air different from (Rne1) or equal (Rne2) to zero. 
on the characteristics of the canopy, irrigation system, vegetation coverage and vine water status. For example, a drip-irrigated vineyard could have more sensible heat flux than a flood-irrigated vineyard because the average area of soil moistened by drip emitters is less than $3 \%$ of the total area of the vineyard, consequently soil heating increases $H$. Thus, future research will be centered on the effect of canopy geometry, the training system, and vineyard water status on the parameterization of short and long wave solar radiation.

\section{CONCLUSIONS}

Two simple models were evaluated for estimating net radiation over a drip-irrigated Cabernet Sauvignon vineyard trained on a vertical shoot-positioned system. Statistical analysis indicated that Rne1 and Rne2 models were capable of estimating Rn with errors below $9 \%(b=0.91)$. The $Z$-test showed that $b$ value was significantly less than 1.0 , indicating that the models tended, in global terms, to overestimate net radiation flux for periods of $30 \mathrm{~min}$ and $24 \mathrm{~h}$. The largest errors were observed under cloudy atmospheric conditions, when MAE ranged between 31 and $40 \mathrm{~W}$ $\mathrm{m}^{-2}$ and RMSE varied between 46 and $61 \mathrm{~W} \mathrm{~m}^{-2}$. On the other hand, this study showed that incorporation of canopy (foliage) temperature did not substantially improve the Rn estimation, in spite of a temperature gradient between air and canopy that ranged from -3 to $4{ }^{\circ} \mathrm{C}$. These results suggest that the proposed model (Rne2) can be used to estimate Rn, using solar radiation, air temperature and relative humidity as variables.

\section{R E S U M E N}

Evaluación de un modelo para simular el flujo de radiación neta sobre un viñedo cv. Cabernet Sauvignon. Marcos Carrasco ${ }^{1}$, y Samuel OrtegaFarías $^{1 *}$. El flujo de radiación neta (Rn) es el principal componente del balance de energía que determina los procesos de evaporación y transpiración. En este contexto, este estudio evaluó dos modelos para estimar Rno sobre un viñedo (Vitis vinifera L. cv. Cabernet Sauvignon) comercial ubicado en el Valle de Pencahue, Región del Maule (3522' S; $71^{\circ} 47^{\prime}$ ' Oeste; 75 m.s.n.m.). Para esto, se ubicó una estación meteorológica automática (AME) en la parte central del viñedo para medir $\mathrm{Rn}$, radiación solar (Rsi), temperatura del aire (Ta), temperatura del dosel (Tf) y humedad relativa (HR). En intervalos de tiempo de $30 \mathrm{~min}$, los resultados indicaron que el modelo Rne 1 (asumiendo Ta $\neq$ Tf ) y el modelo Rne2 (asumiendo $\mathrm{Ta}=\mathrm{Tf}$ ) fueron capaces de estimar Rno con un error absoluto medio (MAE) menor a $40 \mathrm{~W} \mathrm{~m}^{-2}$ y un error del cuadrado medio (RMSE) menor a $61 \mathrm{~W} \mathrm{~m}^{-2}$. En términos diarios, los modelos estimaron Rno con valores de MAE y RMSE inferiores a 1,68 y 1,75 MJ $\mathrm{m}^{-2} \mathrm{~d}^{-1}$, respectivamente. En términos globales, los modelos presentaron errores menores a 9 y $11 \%$ para intervalos de tiempo de $30 \mathrm{~min}$ y diarios, respectivamente. Además, este estudio indicó que la incorporación de la temperatura del dosel (follaje) no mejoró sustancialmente la estimación de Rno, a pesar de tener un gradiente de temperatura $(\mathrm{dT}=\mathrm{Tf}-\mathrm{Ta})$ entre -3 y $4{ }^{\circ} \mathrm{C}$. Estos resultados sugieren que el modelo Rne2 podría ser utilizado para estimar Rno usando mediciones de Rsi, Ta y RH,

Palabras clave: emisividad atmosférica, radiación terrestre, radiación atmosférica, balance de energía Vitis vinifera.

\section{ACKNOWLEDGMENTS}

This research was financed by FONDECYT Project $\mathrm{N}^{\circ} 1030314$ and Viña San Pedro. The authors wish to thank the Agronomists César Acevedo, Carlos Poblete and Francisco Jara, alumni of the School of Agronomy, University of Talca, for their participation in data collection and maintenance of the experimental plot. 


\section{LITERATURE CITED}

Acevedo, C., S. Ortega-Farías, Y. Moreno, and F. Cordova. 2005. Effect of four levels of water application on grape composition and midday stem water potential of Vitis vinifera L. cv. Cabernet Sauvignon. Acta Hort. (ISHS) 664:491-497.

Allen, G., L. Pereira, D. Raes, and M. Smith. 1998. Crop evapotranspiration guidelines for computing crop water requirements. 300 p. Irrigation and Drainage Paper $\mathrm{N}^{\circ} 56$. FAO, Rome, Italy.

Anadranistakis, M., Liakatas, A., Kerkides, P., Rizos, S., Gavanosis, J., Poulovassilis, A. 2000. Crop water requirement model tested for crops grown in Greece. Agric. Water Manage. 42:371-385.

Arya, S.P. 2001. Introduction to micrometeorology. 420 p. Academic Press, San Diego, California, USA.

Brotzge, J., and K. Crawford. 2003. Examination of the surface energy budget: A comparison of eddy correlation and bowen ratio measurements systems. J. Hydrometeorol. 4:160-178.

Brotzge, J., and C. Deuchon. 2000. A field comparison among a domeless net radiometer, two fourcomponent net radiometers, and a domed net radiometer. J. Atmos. Oceanic. Technol. 17:1569-1582.

Campbell, G.S. 1995. Introducción a la biofísica ambiental. 188 p. Ediciones Universitarias, Barcelona, España.

CIREN-CORFO. 1997. Estudio agroecológico. VII Región. Tomo I. 322 p. CIREN, Santiago, Chile.

Daamen, C., and K. McNaughton. 2000. Modeling energy fluxes from sparse canopies and understories. Agron. J. 92:837-847.

Irmak, S., A. Irmak, J.W. Jones, A. Howell, J.M. Jacobs, R.G. Allen, and G. Hoogenboom. 2003. Predicting daily net radiation using minimum climatological data. J. Irrig. Drain. Eng. 129:256-269.
Iziomon, M.G., H. Mayer, and A. Matzarakis. 2000. Empirical model for estimating net radiative flux: a case study for three mid-latitude sites with orographic variability. Astrophys. Space Sci. 273:313-330.

Kato, T., R. Kimura, and M. Kamichika, 2004. Estimation of evapotranspiration, transpiration ratio and wateruse efficiency from a sparse canopy using a compartment model. Agric. Water Manage. 65:173191.

Monteith, J., and M. Unsworth. 1990. Principles of environmental physics. 291 p. Edwards Arnold, London, UK.

Ortega-Farías, S., R. Antonioletti, and A. Olioso. 2000. Net radiation model evaluation at an hourly time step for Mediterranean conditions. Agronomie 20:157-164.

Ortega-Farías, S., R. Calderón, N. Martelli, y R. Antonioletti. 2004. Evaluación de un modelo para estimar la radiación neta sobre un cultivo de tomate industrial. Agric. Téc. (Chile) 64:41-49.

Ortega-Farías, S., Olioso, A., Fuentes, S., and Valdes, H. 2006. Latent heat flux over a furrow-irrigated tomato crop using Penman-Monteith equation with a variable surface canopy resistance. Agric. Water Manage. 82:421-432.

Ortega-Farías, S., M. Carrasco, A. Olioso, and C. Poblete. 2007. Latent heat flux over Cabernet Sauvignon vineyard using the Shuttleworth and Wallace model. Irrig. Sci. 25:161-170.

Pieri, P., and Gaudillére, J.P. 2003. Sensitivity to training system parameters and soil surface albedo of radiation intercepted by vine rows. Vitis 42:77-82.

Sene, K.J. 1994. Parameterizations for energy transfers from a sparse vine crop. Agric. For. Meteorol. 71:118. 